\title{
PEMANFAATAN SOFTWARE GEOGEBRA MELALUI APLIKASI ANDROID PADA MATERI PERSAMAAN KUADRAT
}

\author{
LILIS HANDAYANI \\ SMP Negeri 1 Buduran \\ e-mail: li2s.handayani@gmail.com
}

\begin{abstract}
ABSTRAK
Tujuan penelitian ini untuk mengetahui software geogebra pada materi persamaan kuadrat mata pelajaran matematika. Software geogebra merupakan software berbantuan matematika untuk menggambar grafik, menggambar bangun datar maupun ruang serta dapat juga menggunakan aplikasi ini untuk menghitung suatu luasan volume. Dari penelitian ini didapatkan hasil yang memuaskan diantaranya adanya peningkatan rata rata hasil belajar siswa dari pra siklus sebesar 57,78, siklus I sebesar 78,83 dan siklus II sebesar 84,17 yang disertai dengan peningkatan prosentase ketuntasan belajar matematika pada materi persamaan kuadrat dari pra siklus $21 \%$, siklus I 74\% dan siklus II 87\%. Serta keaktifan siswa dalam pembelajaran matematika semakin meningkat dilihat dari setiap pertemuan yang dilakukan terjadi tanya jawab didalam belajar pembelajaran.
\end{abstract}

Kata Kunci : Software Goegebra, Penelitian Tindakan Kelas, Persamaan Kuadrat

\section{PENDAHULUAN}

Saat ini, teknologi telah menjadi salah satu media pembelajaran yang banyak digunakan. Melalui kemajuan teknologi yang bersinergi dengan pendidikan, diharapkan dapat mempermudah dan meningkatkan kualitas belajar mengajar didunia pendidikan. Salah satu teknologi yang mudah dimanfaatkan adalah Android. Android merupakan sistem operasi berbasis Linux yang dirancang untuk perangkat bergerak layar sentuh seperti telepon pintar (smartphone) dan komputer tablet.

Menurut hasil survey Asosiasi Penyelenggara Jasa Internet Indonesia (APJII) sampai dengan 23 April 2018, pengguna internet di Indonesia mencapai 143,26 juta jiwa. Dimana $58,08 \%$ berada pada wilayah Jawa dan sebanyak 48,53\% dari total pengguna merupakan remaja tingkat Sekolah Menengah Pertama (SMP). Berdasarkan eMarketer, pengguna smartphone di Indonesia akhir tahun 2016 sebanyak 65,2 juta dan meningkat menjadi 74,9 juta pada tahun 2017 (Budiman, 2017). Lembaga riset digital marketing eMarketer memperkirakan pada 2018 jumlah pengguna aktif smartphone di Indonesia lebih dari 100 juta orang.

Saat ini, sudah banyak peserta didik tingkat SMP yang memiliki smartphone berbasis android. Hal ini dapat menjadi peluang untuk pengajar dalam menciptakan metode belajar yang baru. Pengajar dapat memanfaatkan perangkat lunak (software) berbasis android dalam proses belajar mengajar khususnya mata pelajaran matematika. Matematika sebagai salah satu bidang dalam pembelajaran disekolah yang mendapat perhatian dalam pengembangan pembelajarannya. Matematika dapat dianggap sebagai pelajaran yang menantang, karena memerlukan pemahaman teori dan formula. Sehingga diperlukan bahan ajar yang efektif \& efisien agar memudahkan peserta didik dalam memahami matematika. Menurut Yilmaz (2010) dalam (Budiman, 2017), faktor-faktor yang mempengaruhi sikap peserta didik terhadap matematika adalah bahan ajar yang digunakan oleh pengajar, manajemen kelas, pengetahuan dan kepribadian pengajar, serta metode pengajaran. Selain itu, mata pelajaran matematika tingkat SMP yang cenderung abstrak, menyebabkan matematika merupakan salah satu mata pelajaran yang dianggap sulit oleh peserta didik.

Matematika merupakan salah satu disiplin ilmu yang sarat dengan suatu bilangan dan memiliki berbagai macam cabang, salah satu diantaranya adalah aljabar. Aljabar merupakan suatu cabang matematika yang erat kaitannya dengan penjabaran suatu konsep pada matematika. Salah satu konsep yang terdapat pada aljabar adalah konsep persamaan kuadrat. 
Persamaan kuadrat merupakan suatu persamaan dimana pangkat tertinggi variabelnya adalah 2 atau dalam bentuk matematis dapat ditulis yaitu $a x^{2}+b x+c=0 a, b, c \in R$ dan $a \neq 0$. Persamaan kuadrat sering juga disebut sebagai persamaan pangkat dua.

Berdasarkan pengalaman lapangan masih banyak peserta didik yang mengalami kesulitan dalam memahami materi persamaan kuadrat dan belum mampu menguasai konsepkonsep dasar persamaan kuadrat. Berdasarkan hasil tes diagnostik dan wawancara diperoleh hasil bahwa letak kesulitan peserta didik dalam menyelesaikan permasalahan yang berkaitan dengan persamaan kuadrat adalah sebagai berikut: Pertama, memahami akar/selesaian persamaan kuadrat, kesulitan peserta didik terletak pada ketidakmampuan peserta didik dalam menghubungkan antara variabel dan akar. Kedua, menentukan akar/selesaian persamaan kuadrat, dalam menentukan akar/selesaian persamaan kuadrat peserta didik lebih cenderung menggunakan cara pemfaktoran dan rumus kuadrat. Dalam menggunakan cara pemfaktoran mereka lebih banyak menggunakan cara coba-coba (trial and error). Dalam memahami pemfaktoran sebagian besar peserta didik tidak memahami konsep jika dan hanya jika atau. Ketiga, menentukan persamaan kuadrat jika diketahui akar-akarnya, kesulitan peserta didik terletak pada ketidakmampuan peserta didik menghubungkan antara konsep menentukan akar jika diketahui persamaan kuadratnya dengan menentukan persamaan kuadrat jika diketahui akar-akarnya. Sehingga dua hal tersebut dianggap tidak saling berhubungan.

Penggunaan teknologi menjadi penting karena dapat mempengaruhi isi dan tujuan pembelajaran, dan sebagai media untuk meningkatkan proses belajar mengajar dan berperan penting dalam pengembangan proses pendidikan. Teknologi yang dapat digunakan dalam preoses pembelajaran di kelas sudah banyak dikembangkan, salah satunya adalah GoeGebra. Geogebra merupakan salah satu perangkat lunak (software) matematika yang telah dikembangkan untuk membantu pengajaran dan pembelajaran matematika. Pengajar dapat menggunakan Geogebra untuk merancang pembelajaran yang efektif. GeoGebra sangat bermanfaat sebagai media pembelajaran matematika seperti: media demonstrasi dan visualisasi, perangkat konstruksi, dan perangkat untuk membantu proses penemuan (Hohenwarter dan Fuchs, 2004 dalam (Budiman, 2017)).

Dari uraian masalah diatas menunjukkan perlunya pengembangan cara pembelajaran menggunakan program Geogebra dengan memanfaatkan smartphone berbasis android. Gagasan ini penulis sajikan dalam bentuk penelitian tindakan kelas yang berjudul Pemanfaatan Software Geogebra Melalui Aplikasi Android Pada Materi Persamaan Kuadrat.

\section{METODE PENELITIAN}

Penelitian ini merupakan Penelitian Tindakan Kelas (PTK) dimana subjek penelitian ini adalah peserta didik kelas IX-A SMP Negeri 1 Buduran Tahun Pelajaran 2019/2020, dengan jumlah peserta didik sebanyak 39 peserta didik. Data yang diperoleh dari penelitian ini berupa Hasil belajar, keterampilan proses dan respon peserta didik dalam proses pembelajaran yang memanfaatkan sofwear geogebra melalui aplikasi android. Data-data tersebut diperoleh dengan tehnik pengumpulan data, antara lain

a) Test

Menurut Arikunto (2010:266), tes adalah serangkaian pertanyaan atau latihan serta alat lain yang digunakan untuk mengukur ketrampilan, pengetahuan intelegensi, kemampuan atau bakat yang dimiliki oleh individu maupun kelompok. Tes digunakan dengan tujuan untuk mengetahui hasil belajar peserta didik saat pra siklus dan pada tiap siklus atau sesudah memanfaatkan software Geogebra melalui aplikasi Android. Sehingga tiap siklus di peroleh data post test mengenai materi persamaan kuadrat.

b) Observasi, digunakan untuk memperoleh data mengenai keterampilan proses peserta didik dalam proses pembelajaran yang memanfaatkan software geogebra melalui aplikasi android . Observasi dilakukan oleh observer (teman sejawat) yang sebelumnya telah dilakukan diskusi terkait indikator pencapaian keterampilan proses dalam penelitian ini; 
c) Angket, digunakan untuk memperoleh data mengenai respon peserta didik setelah pelaksanaan proses pembelajaran pada tiap siklusnya.

d) Dokumentasi, digunakan untuk memperoleh data mengenai nilai hasil belajar materi persamaan kuadrat pada tahun sebelumnya. Selain itu juga diambil dokumnentasi gambar pada saat pelaksanaan pembelajaran di kelas.

Penelitian ini terdiri dari 2 siklus, dimana tiap siklus terdiri dari tahap : perencanaan, implementasi tindakan, pengamatan/observasi dan refleksi. Berikut rincian tahapan dalam setiap siklus.

\section{Refleksi Awal}

Gagasan ini muncul berdasarkan permasalahan yang ditemukan dalam kegiatan pembelajaran persamaan kuadrat Berdasarkan pengalaman lapangan masih banyak peserta didik yang mengalami kesulitan dalam memahami materi persamaan kuadrat dan belum mampu menguasai konsep-konsep dasar persamaan kuadrat. Berdasarkan hasil tes diagnostik dan wawancara diperoleh hasil bahwa letak kesulitan peserta didik dalam menyelesaikan permasalahan yang berkaitan dengan persamaan kuadrat adalah sebagai berikut: Pertama, memahami akar/selesaian persamaan kuadrat, kesulitan peserta didik terletak pada ketidakmampuan peserta didik dalam menghubungkan antara variabel dan akar. Kedua, menentukan akar/selesaian persamaan kuadrat, dalam menentukan akar/selesaian persamaan kuadrat peserta didik lebih cenderung menggunakan cara pemfaktoran dan rumus kuadrat. Dalam menggunakan cara pemfaktoran mereka lebih banyak menggunakan cara coba-coba (trial and error). Dalam memahami pemfaktoran sebagian besar peserta didik tidak memahami konsep jika dan hanya jika atau. Ketiga, menentukan persamaan kuadrat jika diketahui akarakarnya, kesulitan peserta didik terletak pada ketidakmampuan peserta didik menghubungkan antara konsep menentukan akar jika diketahui persamaan kuadratnya dengan menentukan persamaan kuadrat jika diketahui akar-akarnya. Sehingga dua hal tersebut dianggap tidak saling berhubungan.

2. Siklus I

Secara terperinci prosedur penelitian tindakan kelas dalam siklus pertama diuraikan sebagai berikut :

(1) Perencanaan :

(a) Menentukan tujuan atau kompetensi yang hendak dicapai;

(b) Menentukan media pembelajaran;

(c) Menentukan tahapan proses pembelajaran dengan mengunakan geogebra dalam Hp Android;

(d) Merancang seluruh perangkat pembelajaran dari siklus I hingga siklus II;

(e) Membuat instrument penelitian : soal pre dan post test, lembar pengamatan keterampilan proses dan lembar angket respon peserta didik yang digunakan dari siklus I

hingga siklus II, Diskusi dengan teman sejawat untuk pelaksanaan observasi pada saat proses penelitian di kelas.

(2) Implementasi Tindakan

Tahap ini merupakan tahap implementasi penggunaan geogebra dalam Hp android yang terdiri dari 3 pertemuan, dimana pertemuan pertama merupakan pre test dilanjutkan dengan pembelajaran. Pada proses pembelajaran di awali dengan pemberian apersepsi dan motivasi terhadap materi persamaan kuadrat. Selanjutnya guru juga menyampaikan cara penggunaan software geogebra pada Laptop yang ditampilkan pada tayangan slide dan di lanjutkan dengan penggunaan geogebra dalam $\mathrm{Hp}$ android. Langkah selanjutnya guru meminta peserta didik untuk berdiskusi kelompok dalam menyelesaikan masalah terkait dimana penyelesainnya menggunakan geogebra. kelompok dipilih secara heterogen yang beranggotakan 4-5 peserta didik. Selanjutnya tiap kelompok mempresentasikan hasil 
diskusi. Dan kelompok mengevaluasi hasil presentasi kelompok lain. Pada pertemuan terakhir dilakukan post test mengenai hasil belajar.

(3) Pengamatan

Pengamatan dilakukan untuk memperoleh data mengenai keterampilan proses peserta didik dalam proses pembelajaran yang menggunakan geogebra. Pengamatan keterampilan proses menggunakan instrument pengamatan berupa lembar pengamatan peserta didik. Selian itu pengamatan juga dilakukan untuk mengetahui keterlaksanaan proses pembelajaran secara keseluruhan, dengan menggunakan catatan kecil oleh observer, sehingga pada saat proses refklesi hasil pengamatan mengenai kekurangan ataupun kelebihan dalam proses pembelajaran dapat disampaikan.

(4) Refleksi

Refleksi merupakan kegiatan mengevaluasi dari serangkaian kegiatan dari perencanaan, implementasi dan observasi mengenai kendala, kekurangan dan kelebihan pelaksanaan penelitian pada siklus 1 yang nantinya di perbaiki untuk kelancaran pada siklus selanjutnya. Refleksi dilakukan antara peneliti dan observer serta ahli.

3. Siklus II

Rangkaian kegiatan pada siklus II sama seperti siklus I hanya saja, jika ada perbaikan dari perencanaan yang telah dibuat di siklus I maka dilakukan perencanaan kembali untuk memperbaiki proses pembelajaran.

\section{HASIL DAN PEMBAHASAN}

Masalah dan Pemecahannya

Pada kegiatan observasi awal, melalui observasi maupun melalui pelaksanaan pembelajaran yang dilakukan guru dan observer. Kemudian dilaksanakan analisis untuk menemukan permasalahan-permasalahan dalam pembelajaran yang terjadi di kelas. Adapun permasalahan yang terjadi adalah : (1) peserta didik kurang aktif dalam pembelajaran karena pembelajaran dilaksanakan dengan media pembelajaran yang dilakukan oleh guru., (2) peserta didik banyak yang mencontek karena peserta didik kurang menguasai konsep pada saat evaluasi, (3) pada saat proses pembelajaran guru kurang melibatkan peserta didik dalam menemukan konsep, (4) peserta didik kurang bertanggung jawab dalam mengerjakan tugas/evaluasi serta pada saat diskusi. Solusi yang ditempuh dengan memanfaatkan softwear Geogebra melalui aplikasi Android yang dimiliki peserta didik.

Hasil yang diperoleh :

Tabel 2 : Data Respon Siswa Setelah Pembelajaran

\begin{tabular}{|l|c|c|c|c|}
\hline NO & SISWA & JUMLAH & PERSENTASE & KETERANGAN \\
\hline 1. & $\mathrm{Aa}$ & 36 & $90 \%$ & Sangat Praktis \\
\hline 2. & $\mathrm{Ab}$ & 32 & $80 \%$ & Praktis \\
\hline 3. & $\mathrm{Ac}$ & 38 & $95 \%$ & Sangat Praktis \\
\hline 4. & $\mathrm{Ad}$ & 39 & $97,5 \%$ & Sangat Praktis \\
\hline 5. & $\mathrm{Ae}$ & 37 & $92,5 \%$ & Sangat Praktis \\
\hline 6. & $\mathrm{Af}$ & 37 & $92,5 \%$ & Sangat Praktis \\
\hline 7. & $\mathrm{Ag}$ & 32 & $80 \%$ & Praktis \\
\hline 8. & $\mathrm{Ah}$ & 34 & $85 \%$ & Sangat Praktis \\
\hline 9. & $\mathrm{Ai}$ & 39 & $97,5 \%$ & Sangat Praktis \\
\hline 10. & $\mathrm{Aj}$ & 35 & $87,5 \%$ & Sangat Praktis \\
\hline 11. & $\mathrm{Ak}$ & 37 & $92,5 \%$ & Sangat Praktis \\
\hline 12. & $\mathrm{Al}$ & 36 & $90 \%$ & Sangat Praktis \\
\hline 13. & $\mathrm{Am}$ & 38 & $95 \%$ & Sangat Praktis \\
\hline 14. & $\mathrm{An}$ & 33 & $82,5 \%$ & Sangat Praktis \\
\hline 15. & $\mathrm{Ao}$ & 36 & $90 \%$ & Sangat Praktis \\
\hline \multicolumn{2}{|r|}{ JUMLAH } & 535 & $89,9 \%$ & Sangat Praktis \\
\hline
\end{tabular}


Hasil persentase (\%) rata rata yang diberikan oleh peserta didik adalah $89,9 \%$ yang masuk dalam kategori sangat praktis, maka proses pembelajaran materi persamaan kuadrat yang dilakukan dengan menerapkan softwear Geogebra melalui aplikasi Android sangat praktis. Sehingga suasana pembelajaran menjadi lebih interaktif dan peserta didik menjadi lebih aktif mengikuti pembelajaran, sesuai dengan pendapat Manulu, Jumiati dan Setiawan (2019: 68) yang menyebutkan bahwa pembelajaran berbantukan aplikasi Geogebra mendapat respon positif. Hal ini disebabkan karena kegiatan pembelajaran lebih menarik dan tidak monoton, sehingga dapat meningkatkan minat belajar siswa, dan memudahkan terlaksananya tujuan pembelajaran dan tentu akan berpengaruh positif terhadap keberhasilan pembelajaran matematika.

Penggunaan Geogebra melalui aplikasi Android juga dapat menimbulkan peningkatan dalam keterampilan proses dan membantu peserta mencari penyelesaian secara mandiri serta menyampaikan konsep konsep matematika yang mereka miliki. Hal ini juga diperkuat oleh hasil penelitian Zulnaidi \& Zakaria (2012) yang menyampaikan bahwa penggunaan geogebra dapat meningkatkan pengetahuan konseptual dan prosedur. Dimana prosedur tersebut dapat dikategorikan dalam keterampilan proses peserta didik.

Menurut Budiman (2017) Pembelajaran Matematika berbasis Geogebra versi Android memberikan dampak pada peningkatan hasil belajar siswa, hal ini disebabkan karena dengan menggunakan Geogebra peserta didik mendapat kemudahan dalam memahami konsep dan pemecahan masalah

Tabel 2 : Analisis Nilai Hasil Tes Tiap Peserta Didik Siklus I dan Siklus II

\begin{tabular}{|c|c|c|c|c|}
\hline NO & URAIAN & $\begin{array}{c}\text { PRA } \\
\text { SIKLUS }\end{array}$ & SIKLUS I & SIKLUS II \\
\hline 16. & Rata- rata skor & 57,78 & 78,83 & 84,17 \\
\hline 17. & Nilai Maksimal & 93,9 & 100 & 100 \\
\hline 18. & Nilai Minimal & 20 & 50 & 66,7 \\
\hline 19. & $\begin{array}{l}\text { Peserta didik } \\
\text { yang tuntas }\end{array}$ & 8 & 29 & 34 \\
\hline 20. & $\begin{array}{l}\text { Peserta didik } \\
\text { yang tidak } \\
\text { tuntas }\end{array}$ & 31 & 10 & 5 \\
\hline 21. & \% Ketuntasan & $21 \%$ & $74 \%$ & $87 \%$ \\
\hline 22. & $\begin{array}{l}\text { Distribusi Nilai } \\
: \\
0-77,99 \\
78-94,9 \\
95-100\end{array}$ & $\begin{array}{c}31 \\
8 \\
0\end{array}$ & $\begin{array}{c}10 \\
28 \\
1\end{array}$ & $\begin{array}{c}5 \\
31 \\
3\end{array}$ \\
\hline
\end{tabular}

Dari data diatas terlihat adanya peningkatan rata rata hasil belajar siswa dari pra siklus sebesar 57,78, siklus I sebesar78,83 dan siklus II sebesar 84,17 yang disertai dengan peningkatan prosentase ketuntasan belajar matematika pada materi persamaan kuadrat dari pra siklus $21 \%$, siklus I $74 \%$ dan siklus II $87 \%$.

\section{KESIMPULAN}

Penggunaan "Software Geogebra melalui Aplikasi Android" pada kegiatan pembelajaran peserta didik dapat meningkatkan hasil belajar secara signifikan, ditandai adanya respon positif, suasana belajar lebih menarik, interaktif, peserta didik lebih aktif.

\section{DAFTAR PUSTAKA}

Arikunto, S. 2010. Prosedur Penelitian: Suatu Pendekatan Praktik. Jakarta: Rineka Cipta 
APJII. (2018). Potret Zaman Now Pengguna \& Perilaku Internet Indonesia.

Budiman, H. (2017). Pengembangan Bahan Ajar Matematika SMA Berbasis Geogebra Versi Android. 3(2).

Fitriasari, P. (2017). Pemanfaatan Software Geogebra Dalam Pembelajaran matematika. pp. 57 69.

Manulu, ACS, Jumilah, Y., \& Wahyu, S. (2019). Analisi Minat Belajar Matematika Siswa SMP Kelas VIII Materi Persamaan Garis Lurus Berbantu Aplikasi Geogebra. Journal On Education, Vol.02. No.01.63 - 69

Purwanto. (2011). Evaluasi Hasil Belajar. Yogyakarta: Pustaka Pelajar.

Prayitno, H., Wiryoatmo, S., \& Buchori, A. (2014). Pengembangan Lembar Kerja Peserta didik Matematika SMP Berbantuan Software GeoGebra dengan Pendekatan Realistic Mathematic Education pada Materi Segitiga dan Segiempat Kelas VII SMPN 2 Pucakwangi. Semarang: Universitas PGRI Semarang

Wikipedia. (2013). Wikipedia Ensiklopedia Bebas. Retrieved Agustus 22, 2018, from https://id.wikipedia.org/wiki/Android_(sistem_operasi)

Zulnaidi dan Zakaria. 2012.The Effect of Using GeoGebra on Conceptual and Procedural Knowledge of High School Mathematics Students. Vol. 8, No. 11. Dalam www.ccsenet.org/ass diakses 3 Oktober 2017 